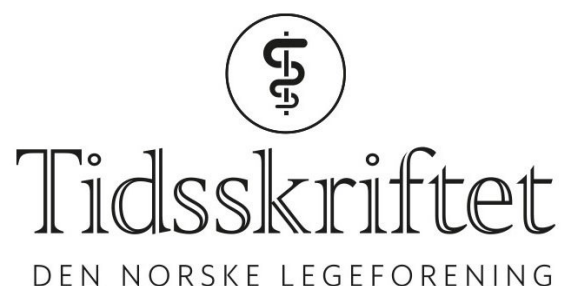

DEN NORSKE LEGEFORENING

\title{
I.M. Grønseth og medarbeidere svarer
}

KOMMENTAR

\section{INGA MARTHE GRØNSETH}

E-post: i.m.gronseth@gmail.com

Inga Marthe Grønseth er allmennlege i spesialisering ved RELIS Midt-Norge og Avdeling for klinisk farmakologi, St. Olavs hospital.

TORBJØRN NAG

PÅL-DIDRIK HOFF ROLAND

Ingen av forfatterne har oppgitt interessekonflikter.

Vi vil takke Eivind C. Borna og Morten Melsom for deres tilsvar til vår kronikk om økning av inhalerte kortikosteroider ved astmaforverring.

Vi er enige $i$ at astma er en heterogen tilstand med mange fenotyper som til dels har forskjellig respons på medikamenter, inkludert inhalerte kortikosteroider. Artiklene vi viser til i vår kronikk kan ikke utelukke at det finnes subgrupper der en midlertidig økning kan være effektivt, eller for den saks skyld gjøre situasjonen verre. Så vidt vi vet finnes det ikke gode studier på dette. For hele gruppen av pasienter med astma ser $\emptyset$ kning av inhalerte kortikosteroider ved astmaforverring ut til å ha liten effekt, dels med økte bivirkninger, spesielt hos barn (1).

Formålet med vår kronikk er å adressere norsk praksis med dobling av inhalasjonssteroider ved forverringer, og (den manglende) evidensen bak dette. Et annet formål har vært å påpeke viktigheten av god opplæring og etterlevelse hos pasienter med astma. Studien på barn (1) er en randomisert dobbeltblindet kontrollert studie med strenge krav til og loggføring av etterlevelse. Barna i studien var mye mindre syke enn forventet og hadde ingen effekt av økning av inhalerte kortikosteroider. Studien på voksne (2) er en virkelighetsstudie («real life»-studie) uten intervensjon med tanke på etterlevelse. Vanligvis antas det at etterlevelsen av inhalert kortikosteroidbehandling er dårlig hos minst halvparten av astmapasientene (3). Man ser da en liten effekt som mest sannsynlig skyldes at de bruker inhalerte steroider i høye doser intermitterende.

Når det gjelder beta2-agonister refereres det i tilsvaret til en artikkel (4), der forfatteren i sin konklusjon påpeker at det er sannsynlig at den gode effekten av beta2-agonister og derav overforbruk av disse fører til underforbruk av forebyggende legemidler (hovedsakelig inhalerte kortikosteroider). At fokus på opplæring og etterlevelse hos pasienter med astma vil gi bedre symptomkontroll og dermed også redusere behovet for beta2-agonister belyses altså også her.

Det presiseres at vår kronikk kun gjelder midlertidig økning av inhalerte kortikosteroider 
og bruk av anbefalte doser beta2-agonister ved forverringer. Pasienter som er dårlig kontrollert, skal få $\emptyset \mathrm{kt}$ sine faste medisiner, og eksaserbasjoner bør behandles med beta2agonister og andre medisiner i tråd med nasjonale og internasjonale retningslinjer.

\section{LITTERATUR:}

1. Jackson DJ, Bacharier LB, Mauger DT et al. National Heart, Lung, and Blood Institute AsthmaNet. Quintupling inhaled glucocorticoids to prevent childhood asthma exacerbations. N Engl J Med 2018; 378: 891-901. [PubMed][CrossRef]

2. McKeever T, Mortimer K, Wilson A et al. Quadrupling inhaled glucocorticoid dose to abort asthma exacerbations. N Engl J Med 2018; 378: 902-10. [PubMed][CrossRef]

3. Bårnes CB, Ulrik CS. Asthma and adherence to inhaled corticosteroids: current status and future perspectives. Respir Care 2015; 60: 455-68. [PubMed][CrossRef]

4. Cockcroft DW. Clinical concerns with inhaled beta2-agonists: adult asthma. Clin Rev Allergy Immunol 2006;31:197-208. [PubMed][CrossRef]

Publisert: 8. april 2019. Tidsskr Nor Legeforen. DOI: 10.4045/tidsskr.19.0216

(C) Tidsskrift for Den norske legeforening 2020. Lastet ned fra tidsskriftet.no 